\title{
PENERAPAN APLIKASI SISTEM INFORMASI MANAJEMEN DAN DESIGN LAYANAN DRIVE THRU PADA USAHA KAFE RUMAH SUSU DI PADANG PANJANG
}

\author{
Fitrimawati, Ramaiyulis dan Aronal Arief Putra \\ Universitas Andalas, Padang, Indonesia \\ Email: fitrimawati@yahoo.com
}

Received: 08 Juli 2018. Accepted : 25 Agustus 2018. Published Online 10 September 2018

\begin{abstract}
ABSTRAK
Ilmu dan teknologi untuk masyarakat telah diaplikasikan di Kafe Rumah Susu yang terletak di jalan Kiayi Kamarulloh Kecamatan. Bukik Surungan Kota Padang Panjang. Seiring dengan perkembangan usaha, kafe rumah susu ini mengalami permasalahan dalam merumuskan strategi dalam perkembangan usaha dan peningkatan penjualan. Salah satu solusi yang dilakukan adalah pendekatan Sistem Informasi Manajemen (SIM). Aplikasi SIM dilakukan bertujuan agar data usaha mitra lengkap dan akurat serta tersedia sepanjang waktu. Solusi untuk peningkatan pemasaran adalah membuat design layananan drive thru sedernana namun menarik. Pesanan dipesan dan layanan diberikan melalui jendela khusus, sementara konsumen tetap berada dalam kendaraan mereka. Metode pelaksanaan program ini adalah dengan metode demonstrasi. Hasil pelaksanaan program adalan aplikasi SIM dengan data usaha mitra lengkap dan akurat serta tersedia sepanjang waktu. SIM dapat menyediakan informasi untuk menunjang proses pengambilan keputusan yang akan diambil manajer, memungkinkan keputusan dapat diambil lebih cepat dan tepat. Pengolahan transaksi dalam SIM memungkinkan manajer dapat dengan mudah mengawasi kekayaan perusahaan, memantau perkembangan usaha dan memberikan laporan kepada stakeholders. Solusi untuk peningkatan pemasaran adalah membuat design layananan drive thru sedernana namun menarik. Pesanan dipesan dan layanan diberikan melalui jendela khusus, sementara konsumen tetap berada dalam kendaraan mereka. Tujuan drive thru adalah memudahkan konsumen yang ingin mendapatkan produk secara cepat tapi enggan turun dari kendaraannya (mobil/motor). Layanan drive thru ini dapat menghemat waktu konsumen untuk menikmati makana fast food. Melalui layanan ini konsumen mampir, dapat lalu pergi dalam waktu 3 menit.
\end{abstract}

Kata Kunci: aplikasi, sistem informasi manajemen, drive THRU, kafe rumah susu

\section{Application of Management Information System and Drive THRU Service Service on Milk House Cafe Business in Padang Panjang}

\begin{abstract}
Science and technology for the community have been applied at the Milk House Cafe located on Kiayi Kamarulloh Street, Bukik Surungan, Padang Panjang city. Along with the development of the business, this dairy café has experienced problems in formulating strategies in business development and increasing sales. One solution is the Management Information System (SIM) approach. The SIM application is conducted so that the partner's business data is complete and accurate and is available at all times. The solution to improving marketing is to make the design of the service drive simple but attractive. Orders are ordered and services are provided through a special window, while consumers remain in their vehicles. The method of implementing this program is the demonstration method. The results of program implementation are SIM applications with complete and accurate partner business data and are available at all times. SIM can provide information to support the decision-making process that the manager will take, allowing decisions to be taken faster and precisely. Processing transactions in SIM allows managers to easily supervise company assets, monitor business developments and provide reports to stakeholders. The solution to improving marketing is to make the design of the service drive simple but attractive. Orders are ordered and services are provided through a special window, while consumers remain in their vehicles. The purpose of the drive thru is to facilitate consumers who want to get products quickly but are reluctant to get off their vehicles (cars / motorbikes). This drive thru service can save
\end{abstract}


consumers time to enjoy fast food. Through this service consumers stop by, can then leave within 3 minutes.

Keyword: application, management information system, drive THRU, milk home cafe

\section{PENDAHULUAN}

Salah satu diantara hasil komoditi peternakan yang telah dikenal luas adalah susu. Susu merupakan komoditi tarpenting dari aspek kesehatan dan merupakan produk pangan asal ternak yang mempunyai peluang besar dari aspek bisnis. Dari kandungan nilai gizi, susu dapat memenuhi kebutuhan gizi bagi masyarakat dan mencegah terjadinya lost generation (generasi yang penuh dengan keterbatasan, seperti kualitas individu yang rendah, baik ditinjau dari segi kesehatan, kecerdasan dan kemampuan berpikir, maupun mental). Susu juga memiliki nilai ekonomi untuk peningkatan kesejahteraan masyarakat sebagai penyedia lapangan kerja (Badan Penelitian dan Pengembangan Pertanian, 2009).

Bisnis yang mengolah produk yang berbahan dasar susu saat ini dan yang banyak di minati masyarakat adalah kafe rumah/gerai susu. Salah satu usaha rumah susu segar yang sedang berkembang dan populer di Sumatra Barat yaitu Kafe Rumah Susu yang terletak di jalan Kiayi Kamarulloh Kec.Bukik Surungan kota Padang Panjang. Kafe Rumah susu ini memiliki letak yang strategis, yaitu lokasi yang berada di tepi jalan lintas Padang-Bukit Tinggi, di mana merupakan jalan wisatawan menuju kota Bukit Tinggi. Usaha ini berdiri pada tahun 2015, yang didirikan oleh Dinas Pertanian Kota Padang Panjang dengan modal awal 3,2 milyar. Usaha ini di jalankan oleh Ibu Erni Wati S.Pt. dengan jumlah karyawan sebanyak 5 orang. Kafe rumah susu yang didirikan pada tahun 2015 sampai sekarang memiliki perkembangan yang sangat pesat. Pada awalnya konsumen kafe rumah susu ini hanya penduduk kota Padang Panjang saja sekarang sudah banyak orang-orang dari luar kota Panjang Panjang yang mengunjungi kafe rumah susu tersebut termasuk wisatawan-wisatawan yang akan ke Bukit Tinggi dari arah Padang, Solok, BatuSangkar, Pariaman dan Padang Panjang dan wisatawan dari Bukit Tinggi menuju Padang.

Dengan adanya variasi produk hasil olahan susu yang di minati masyarakat dan di sertai dengan pelayanan yang baik, maka usaha kafe rumah susu ini semakin banyak di kunjungi konsumen. Kafe ini sejak berdiri sampai sekarang mengalami peningkatan pembeli atau konsumen yang awalnya hanya penduduk kota Padang Panjang saja, sekarang selain penduduk kta Padang Panjang, di luar kota Padang Panjang juga sudah mengunjungi dan membeli susu di kafe rumah susu kota Padang Panjang tersebut di antaranya seperti konsumen yang berasal dari kota Padang, kota Bukit Tinggi dan para wisatawan-wisatawan dari luar Sumatera Barat seperti Riau, Medan dan Jambi.

Seiring dengan perkembangan yang dialami, usaha susu segar ini mengalami permasalahan dalam peningkatan pemasaran. Peluang pasar yang amat besar, tidak dapat ditangkap oleh mereka. Hal ini disebabkan karena masih banyaknya kendala yang mereka hadapi untuk dapat berkembang. Kendala ini salah satunya disebab ketidakmampuan pemilik untuk menciptakan strategi yang andal dan menangkap pasar dengan efisien. Hal ini disebabkan karena data dan informasi untuk merumuskan strategi tidak dimiliki dengan lengkap. Usaha ini tidak mempunyai pembukuan usaha yang detail, akurat dan tidak tersedia setiap waktu. Usaha belum melakukan manajemen 
usaha secara baik.

Usaha kafe Rumah Susu Padang Panjang belum mempunyai manajemen data yang rinci dan teratur baik secara manual maupun elektronik terhadap penjualan produk, pasokan susu, penerimaan dan pengeluaran usaha serta catatan personalianya. Akibatnya pemilik usaha sangat kesulitan merancang strategi peningkatan produksi dan pemasaran. Pemilik tidak mempunyai cukup informasi yang diperoleh dari data yang ada. Permasalahan yang paling krusial sekali pun didalam bisnis yaitu keuntungan yang diperoleh sangat tidak dapat diketahui dengan pasti terutama pada usaha Kafe Rumah Susu Padang Panjang dimana usahanya sudah cukup luas baik dari variasi produk yang dijual mahupun distribusi produk pada gerai-gerai yang mereka miliki di beberapa tempat. Hal ini disebabkan karena kurangnya pencacatan yang detail dan akurat terhadap proses usaha. Padahal dalam persaingan yang semakin ketat, informasi menjadi salah satu sumberdaya yang harus dikelola secara baik sehingga dapat menciptakan nilai tambah bagi perusahaan tersebut.

Informasi merupakan salah satu sumber daya penting dalam manajemen moderen, banyak keputusan strategis yang bergantung kepada informasi. Sumber daya informasi merupakan salah satu bagian dari 4M+1I yang mencakup manusia, material, mesin dan modal serta informasi merupakan sumber daya vital bagi kelangsungan organisasi bisnis (Alter, 2009). Salah satu manajemen informasi yang diterapkan dalam manajemen modern adalah Sistem Informasi Manajemen (SIM). SIM adalah sebuah sistem berbasis komputer. Software Sistem Informasi Manajemen dibuat dengan menggunakan Microsoft Acces dan Microsoft Visual Basic. SIM dapat digunakan sebagai pengendali bisnis karena dapat menunjang keputusan bisnis dan mencatat seluruh kegiatan transaksi secara sistematis dan terintegrasi. SIM dapat menyediakan informasi untuk menunjang proses pengambilan keputusan yang akan diambil manajer, memungkinkan keputusan dapat diambil lebih cepat dan tepat. Pengolahan transaksi dalam SIM memungkinkan manajer dapat dengan mudah mengawasi kekayaan perusahaan, memantau perkembangan usaha dan memberikan laporan kepada stakeholders.

Permasalahan kedua yang dihadapi oleh usaha penjualan susu segar ini adalah kesulitan dalam peningkatan penjualan. Walaupun usaha mereka meningkat setiap tahunnya namun peningkatan tersebut sangat rendah dan lamban. Terutama usaha Kafe Rumah Susu Padang Panjang yang mempunyai peluang pasar (market share) yang amat besar yang berasal dari wisatawan namun market share yang besar itu tidak maksimal ditangkap oleh kafe Rumah Susu Padang Panjang. Hal ini disebabkan karena penjualan susu melalui pendekatan kafe dimana usaha ini melayani pelanggan dengan menyediakan tempat duduk yang nyaman untuk menikmati variasi produk susu yang mereka jual. Padahal untuk menikmati segelas susu memerlukan waktu lebih kurang beberapa menit saja bahkan satu detik susu sudah ditelan habis. Berbeda dengan produk minuman seperti kopi dan sejenisnya yang dinikmati dalam keadaan panas sehingga konsumen memerlukan tempat duduk untuk menikmatinya. Inilah yang membuat enggannya pelanggan susu untuk mampir karena sangat merepotkan saat parkir kendaraan mereka terutama pada saat hari libur dimana pelanggan amat banyak namun tempat parkir over capacity.

Keberhasilan dan kegagalan sebuah perusahaan salah satunya ditentukan oleh penerapan layanan yang sesuai. Drive thru atau drive through adalah suatu bentuk pelayanan konsumen yang masih berada dalam kendaraan mereka. Pesanan dipesan dan layanan diberikan melalui jendela khusus, sementara konsumen tetap berada dalam kendaraan mereka. Tujuan drive thru adalah memudahkan konsumen yang ingin 
mendapatkan produk secara cepat tapi enggan turun dari kendaraannya (mobil/motor). Layanan drive thru ini dapat menghemat waktu konsumen untuk menikmati makana fast food. Melalui layanan ini konsumen mampir, dapat lalu pergi dalam waktu 3 menit. Prinsip layanan drive thru ini adalah kecepatan pelayanan. Sebagian restoran cepat saji menyadari bahwa lebih dari $60 \%$ bisnis mereka tergantung pada layanan drive thru.

Untuk menyelesaikan dua permasalah usaha mitra maka dilakukan pembuatan dan aplikasi Sistem Informasi Manajemen (SIM) dan membuat design layanan drive THRU di Kafe Rumah Susu Padang Panjang. Diharapkan kedua kegiatan ini akan diaplikasikan oleh mitra.

\section{METODE}

Metode pendekatan yang ditawarkan untuk pelaksanaan kegiatan adalah:

\section{a. Sistem Informasi Manajemen}

Metode pendekatan yang akan digunakan dalam penerapan sistem informasi manajemen di usaha mitra adalah dengan metode demonstrasi. Demonstrasi merupakan suatu metode untuk memperlihatkan secara nyata tentang cara atau hasil penerapan teknologi kepada mitra. Hasil SIM yang telah dihasilkan akan mendemontrsikan cara mengaplikasikannya kepada mitra.

Prosedur Kerja:

- Membuat analisa dengan bantuan informasi dari mitra terhadap workflow sistem informasi yang sedang berjalan di usaha mitra dan mengindentifikasi apakah workflow telah efisien dan sesuai standar tertentu.

- Setelah proses analisa selesai, selanjutnya adalah membuat desain fondasi sistem informasi manajemen di usaha mitra. Ada 2 jenis desain yang dibuat yaitu desain proses bisnis dan desain pemrograman. Desain ini akan menjadi pedoman bagi pengusul untuk menulis source code. Desain pemrograman meliputi :1). Desain database; 2). Desain Screen Layout; 3). Desain Diagram Proses dan 4) Desain Report Layout.

- Pekerjaan yang dilakukan selanjutnya adalah melakukan pemrograman. Pemrograman adalah pekerjaan menulis program komputer dengan bahasa pemrograman berdasarkan algoritma dan logika tertentu.

- Pengabdi melakukan testing untuk mengidentifikasi ketidaksesuaian hasil sebuah sistem informasi dengan hasil yang diharapkan untuk usaha mitra.

- Menerapkan sistem informasi yang telah dibangun agar mitra menggunakannya dan menggantikan sistem informasi yang lama. Proses Implementasi ini dilakukan melalui kegiatan demonstrasi. Beberapa kegiatan dalam demonstrasi adalah : a) Memberitahu mitra; b) Melatih user; c) Memasang sistem (install system); d) Entri/Konversi data; e) Siapkan user ID.

- Mengajarkan kepada mitra cara melakukan pengoperasian dan pemeliharaan. Selama sistem informasi beroperasi, terdapat beberapa pekerjaan rutin yang perlu dilakukan terhadap sistem informasi, antara lain: a) System Maintenance; b) Backup \& Recovery dan c) Data Archive.

\section{b. Drive Thru}

Metode pendekatan yang digunakan untuk mendesign drive thru sederhana pada 
kafe rumah susu Padang Panjang adalah dengan membuat rancangan atau design oleh pengusul dengan bantuan informasi dari mitra. Pengabdi bersama mitra membuat rancangan menu, plang nama dan design drive thru yang lebih menarik.

Prosedur kerja:

- Mitra menyediakan data dan informasi tentang lokasi dan ukuran dibangunnya drive thru di kafe rumah susu Padang Panjang. Mitra menyediakan data tentang produk beserta harganya Produk.

- Membuat rancangan/design drive thru, plang nama, menu dan design agar lebih menarik bersama mitra.

- Rancangan awal akan diperbaiki oleh pengabdi dengan lebih baik

- Membuat rancangan/design drive thru untuk kafe rumah susu Padang Panjang menggunakan komputer.

- Design drive thru beserta menu dan plang nama akan dicetak di digital printing

\section{HASIL DAN PEMBAHASAN}

Usaha Kafe Rumah Susu Padang Panjang adalah usaha susu segar pasteurisasi dengan bermacam rasa dan produk olahan dari susu seperti yoghurt, kefir, permen susu dan lain sebagainya. Penjualan dari produk tersebut dijual dengan sistem penjualan berbentuk kafe. Kafe Rumah Susu Padang Panjang merupakan usaha penjualan susu segar yang tergolong besar di propinsi Sumatera Barat. Pembeli produk susu segar di kafe ini berasal dari daerah sekitar Padang Panjang dan luar kota Padang Panjang. Pembeli banyak bersal dari luar Padang Panjang disebabkan karena kafe ini terletak di pinggir jalan lintas Padang menuju Bukittinggi. Jalan ini ramai dilalui wisatawan menuju kota wisata yaitu Padang dan Bukit tinggi.

\section{Pelaksanaan Program Aplikasi Sistem Informasi Manajemen}

Usaha Kafe Rumah Susu Padang Panjang disamping menjual produknya dalam bentuk kafe juga melakukan pemasokan susu segar pasteurisasi ke Pekan baru dan Palembang. Besarnya usaha kafe ini dan bervariasinya produk yang mereka jual semakin dituntut untuk melakukan managemen yang baik. Salah satu solusi dari manajemen yang dilakukan adalah membuat sistem informasi manajemen. Sistem ini dibuat dengan tujuan agar pemilik mahupun manager mempunyai data yang lengkap dan tersedia sepanjang waktu untuk merumuskan strategi peningkatan penjualan.

Kegiatan yang telah pengabdi lakukan dalam hal ini adalah:

1. Pengabdi mengunjungi mitra Usaha Kafe Rumah Susu Padang Panjang untuk mensosialisasikan pelaksanaan program dan berdiskusi untuk mendapatkan informasi dari mitra tentang workflow sistem informasi yang sedang berjalan di usaha mitra dan mengindentifikasi apakah workflow telah efisien dan sesuai standar tertentu.

2. Setelah proses analisa selesai, selanjutnya adalah pengabdil membuat desain fondasi sistem informasi manajemen di usaha mitra. Ada 2 jenis desain yang dibuat yaitu desain proses bisnis dan desain pemrograman. Desain ini akan menjadi pedoman bagi pengabdi untuk menulis source code. Desain pemrograman meliputi:1). Desain database; 2). Desain Screen Layout; 3). Desain Diagram Proses 
dan 4) Desain Report Layout.

3. Pekerjaan yang dilakukan selanjutnya adalah pengabdi melakukan pemrograman. Pemrograman adalah pekerjaan menulis program komputer dengan bahasa pemrograman berdasarkan algoritma dan logika tertentu.

4. Pengabdi melakukan testing untuk mengidentifikasi ketidaksesuaian hasil sebuah sistem informasi dengan hasil yang diharapkan untuk usaha mitra.

5. Pengabdi menerapkan sistem informasi yang telah dibangun agar mitra menggunakannya dan menggantikan sistem informasi yang lama. Proses Implementasi ini dilakukan melalui kegiatan demonstrasi. Beberapa kegiatan dalam demonstrasi adalah : a) Memberitahu mitra; b) Melatih user; c) Memasang sistem (install system); d) Entri/Konversi data; e) Siapkan user ID.

6. Pengabdi mengajarkan kepada mitra cara melakukan pengoperasian dan pemeliharaan. Selama sistem informasi beroperasi, terdapat beberapa pekerjaan rutin yang perlu dilakukan terhadap sistem informasi, antara lain: a) System Maintenance; b) Backup \& Recovery dan c) Data Archive.

Berikut ini adalah hasil pemograman SIM di Usaha Kafe Rumah Susu Padang Panjang yang dibuat team pengabdi dan di ajarkan penggunaannya kepada mitra untuk diaplikasikan di usaha mitra.

Menu di bawah ini adalah menu login. Untuk memulai pencatatan dan mengoperasionalkan SIM maka manager atau pun karyawan yang bertugas mengoperasionalkan SIM ini mengklik menu login untuk membuka aplikasi.

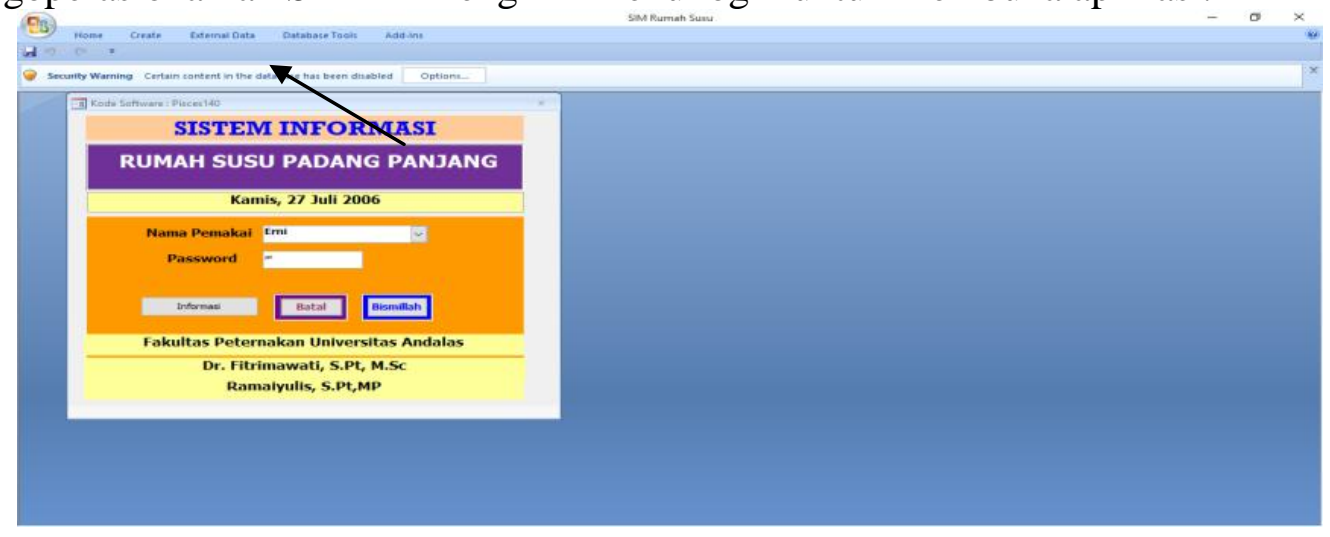

Gambar 1. Menu Login

Setelah program terbuka, maka klik \{option\} seperti pada panah lalu klik \{enable this content \} lalu OK

Lakukan login :

- Isi nama pemakai

- Isi password sesuai nama pemakai yang telah diberika admin

- Klik Bismillah

- Mulailah bekerja dengan menu berikut

Dalam SIM yang dibuat ini terdapat dua menu utama yaitu menu yang akan dioperasikan oleh karyawan dan menu yang dioperasikan oleh pemilik usaha. Selanjutnya karyawan menggunakan menu di bawah ini untuk karyawan. Menu ini berisikan: penjualan produk usaha kafe rumah susu, pengiriman produk, pembelian 
bahan baku, jumlah barang yang diterima, stock produk, dan pemasok, pelanggan, sales

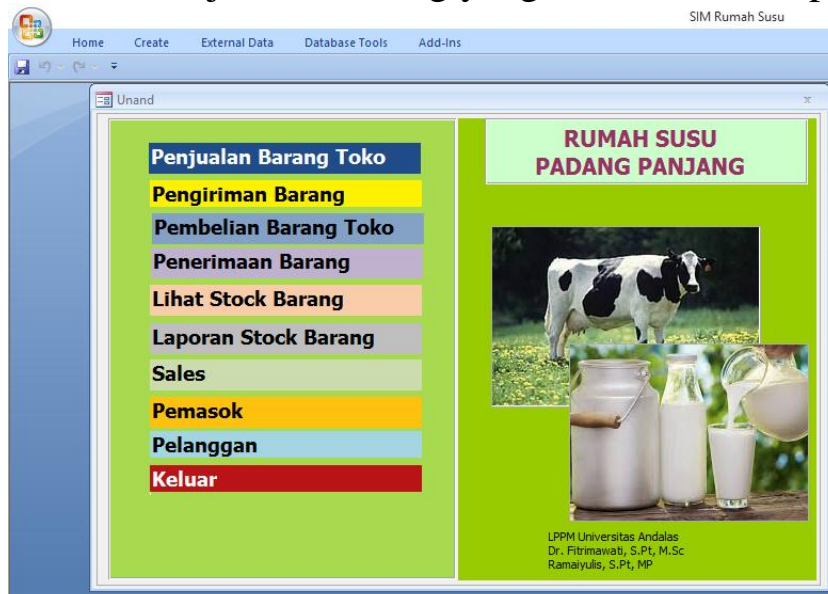

Gambar 2. Menu Operasional

Ini adalah menu produk yang terjual beserta harganya.

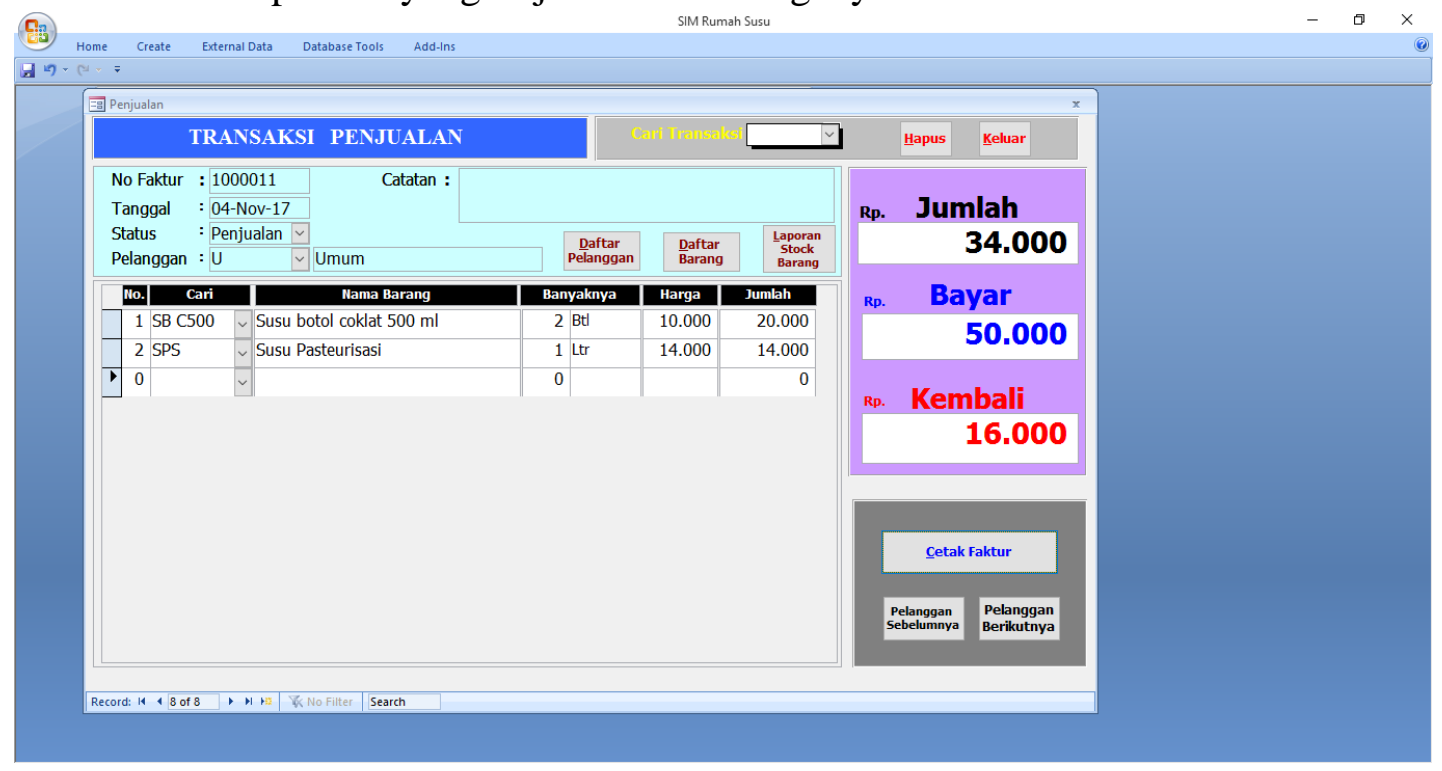

Gambar 3. Menu Produk

Cara Operasional :

- Klik pelanggan isikan berdasarkan pilihan (misal umum)

- Klik panah cari akan keluar pilihan barang yang tersedia lalu klik sesui apa yang dijual (misal susu coklat kemasan $500 \mathrm{ml}$ ), pilihan juga akan muncul dengan menekan F4 dan Esc jika membatalkan

- Isikan jumlah barang yang dijual (misal 2) maka program komputer akan menghitung jumlah dan total penjualan

- Demikian selanjutnya untuk barang berikutnya 
Website. http://hilirisasi.lppm.unand.ac.id

- Isikan jumlah pembayaran (misal 50.000), maka program akan menghitung kembaliannya

- Lalu klik cetak faktur maka program akan mengeluarkan print preview

- Jika ingin mencetak ke printer tekan $\{\mathrm{Ctrl} P\}$ dan enter maka printer akan mencetak faktur penjualan.

- Klik pelanggan berikutnya untuk melanjutkan

- Stock barang tertentu dapat dicek dengan menekan Daftar Barang lalu pilih barang yang diingin diketahui.

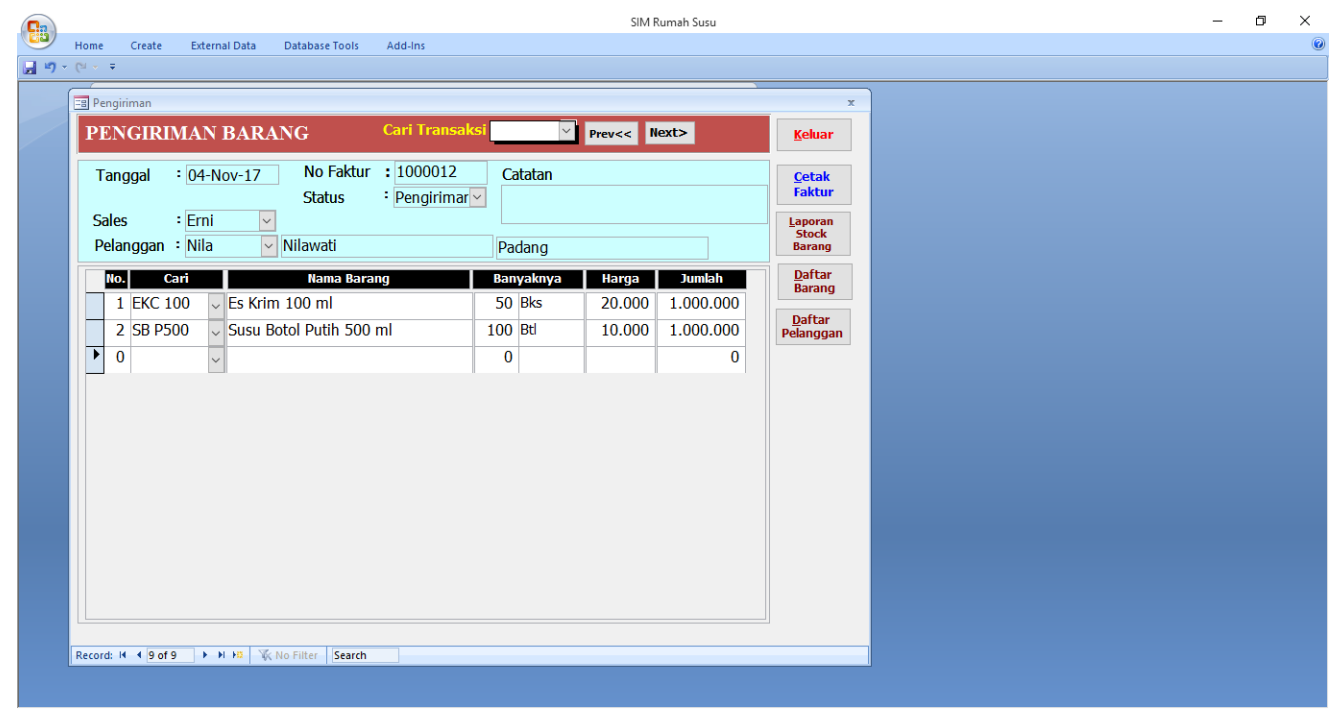

Gambar 4. Menu Pengiriman Barang

Update dafatr barang, daftar pelanggan bisa dilakukan pada menu admin` Jika ada barang baru , maka admin harus menginput barang tersebut terlebih dahulu, baru bisa diakses pada menu penjualan. Ini adalah menu Pengiriman Barang.

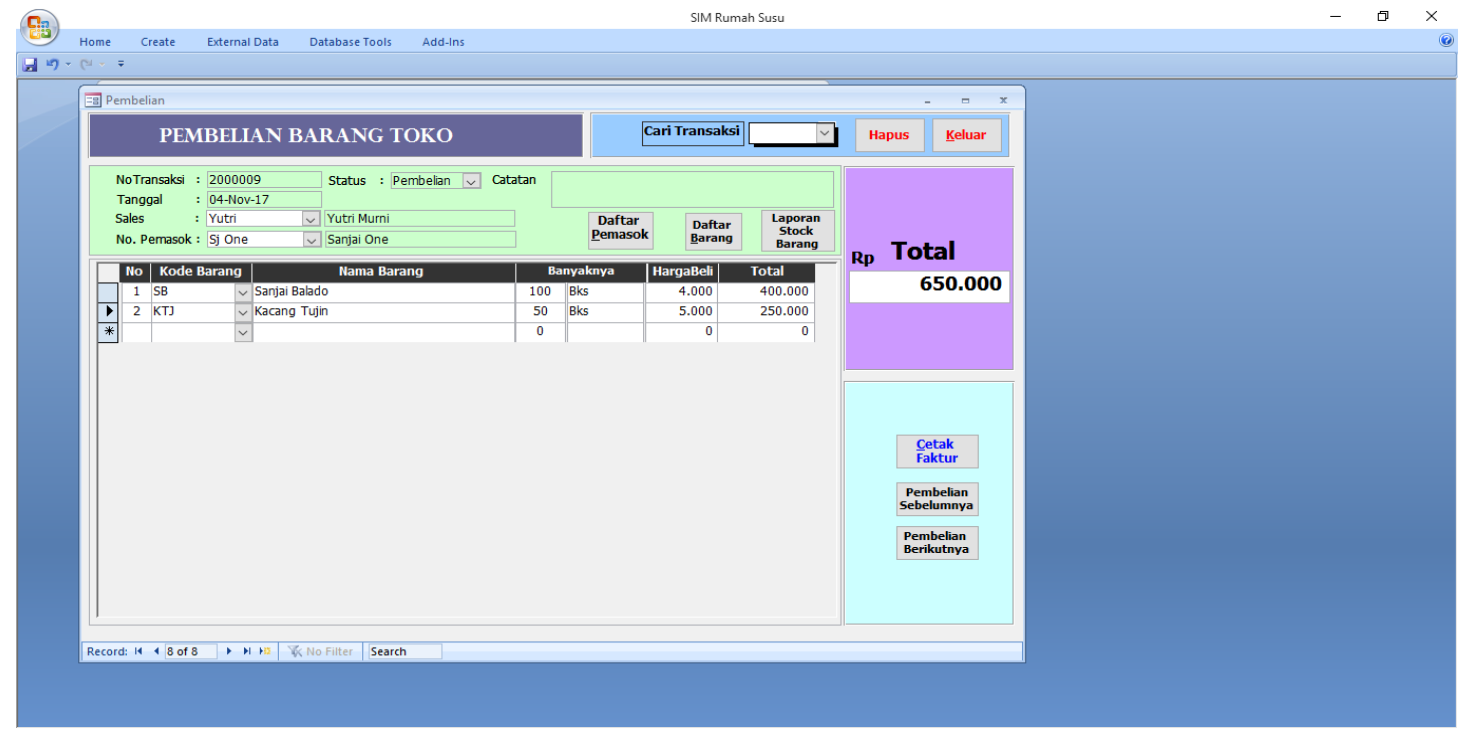

Gambar 5. Menu Pembelian Barang 
Menu ini digunakan untuk pengiriman barang dari toko ke wilayah lain. Cara input hampir sama dengan input penjualan dengan memulai dari \{nama sales\}, terus \{nama pelanggan\} kemana barang dikirim kemudian seterusnya menginput nama barang dan jumlah hingga selesai dan diakhiri dengan cetak Faktur. Berikut adalah menu pembelian barang toko

Menu ini digunakan untuk input pembelian barang toko dari pemasok luar, misalnya sanjai, kerupuk jangek, brownis dan lain-lain. Cara input dimulai dari \{nama sales\}, terus \{nama pemasok\} dan kemudian nama barang yang dipasok dan jumlahnya serta diakhiri dengan cetak faktur.

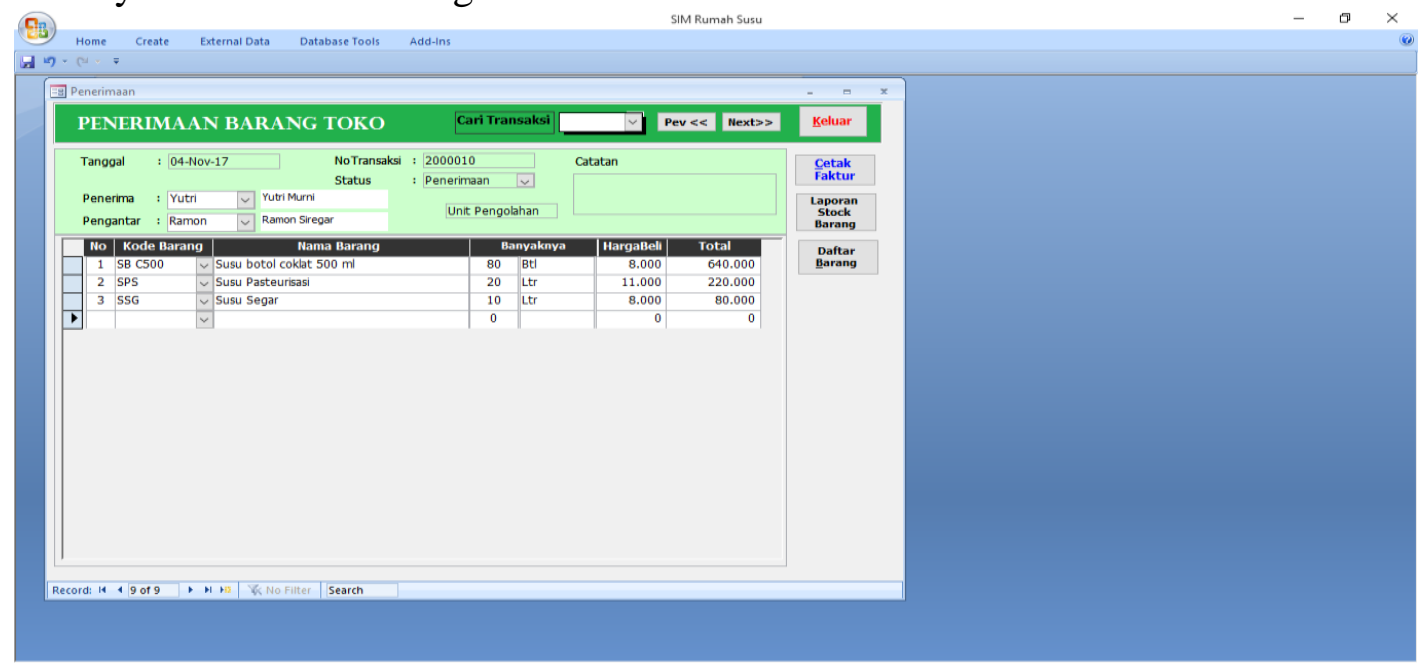

Gambar 6. Menu Input Pembelian Barang

Menu ini digunakan untuk input penerimaan barang toko dari unit pengolahan semua produk yang diolah sendiri. Cara input: dimulai dengan \{nama penerima\}, terus \{nama pengantar\} dilanjutkan barang apasaja yang diterima dan jumlahnya diakhiri dengan cetak faktur. Ini adalah menu laporan stock barang.

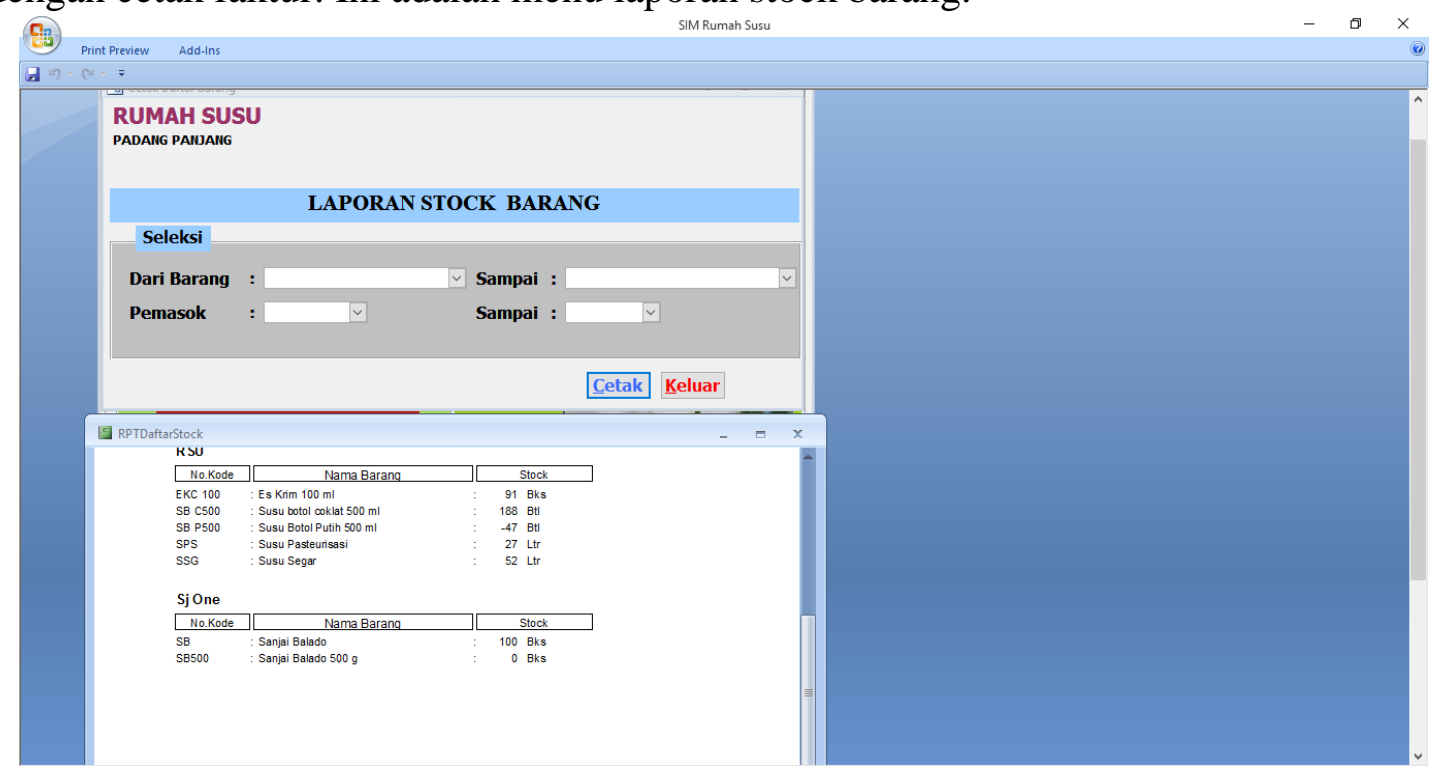

Gambar 6. Menu Laporan Stock Barang 
Menu ini digunakan pada setiap hari akan tutup toko sebagai laporan stock barang akhir yang ada ditoko pada hari itu. Caranya : klik Laporan Stok Barang di menu utama akan keluar pilihan Laporan Stock Barang jika perlu masukan pilihan misalnya pemasok (pilih unit pengolahan) Lalu Klik $\{$ Cetak\}, maka yang akan ditampilkan hanya barang yang berasal dari unit pengolahan. Atau kalau tidak dipilih, maka program akan mengeluarkan jumlah stok dari semua barang baik dari unit pengolahan maupun dari luar (sanjai dan lain-lain)

Beberapa Menu Pendukung :

- Sales $\rightarrow$ berisi informas tentang data sales toko

- Pelanggan $\rightarrow$ berisi data dan informasi tentang pelanggan

- Pemasok $\rightarrow$ berisi data dan informasi tentang pemasok barang

Ini adalah menu Admin Atau Menu Untuk Pemilik Usaha. Jika Login sebagai admin atau pemilik usaha maka menu yang akan muncul berbeda dengan menu karyawan, yaitu menu untuk admin. Sebelum mengisi login, silahkan klik \{option\} lalu klik \{enable this content $\}$ lalu $\{$ ok $\}$ terlebih dahulu. Menu untuk pemilik usaha ini terdiri dari : laporan penjualan toko, laporan pengiriman barang, laporan pembelian barang, jumlah stock barang, laporan penerimaan barang, jumlah stock barang, nilai stock barang, daftar barang, daftar sales, daftar pemasok, dan daftar pelanggan. Menu ini bermanfaat bagi pemilik untuk membuat keputusan strategis dalam perusahaannya.

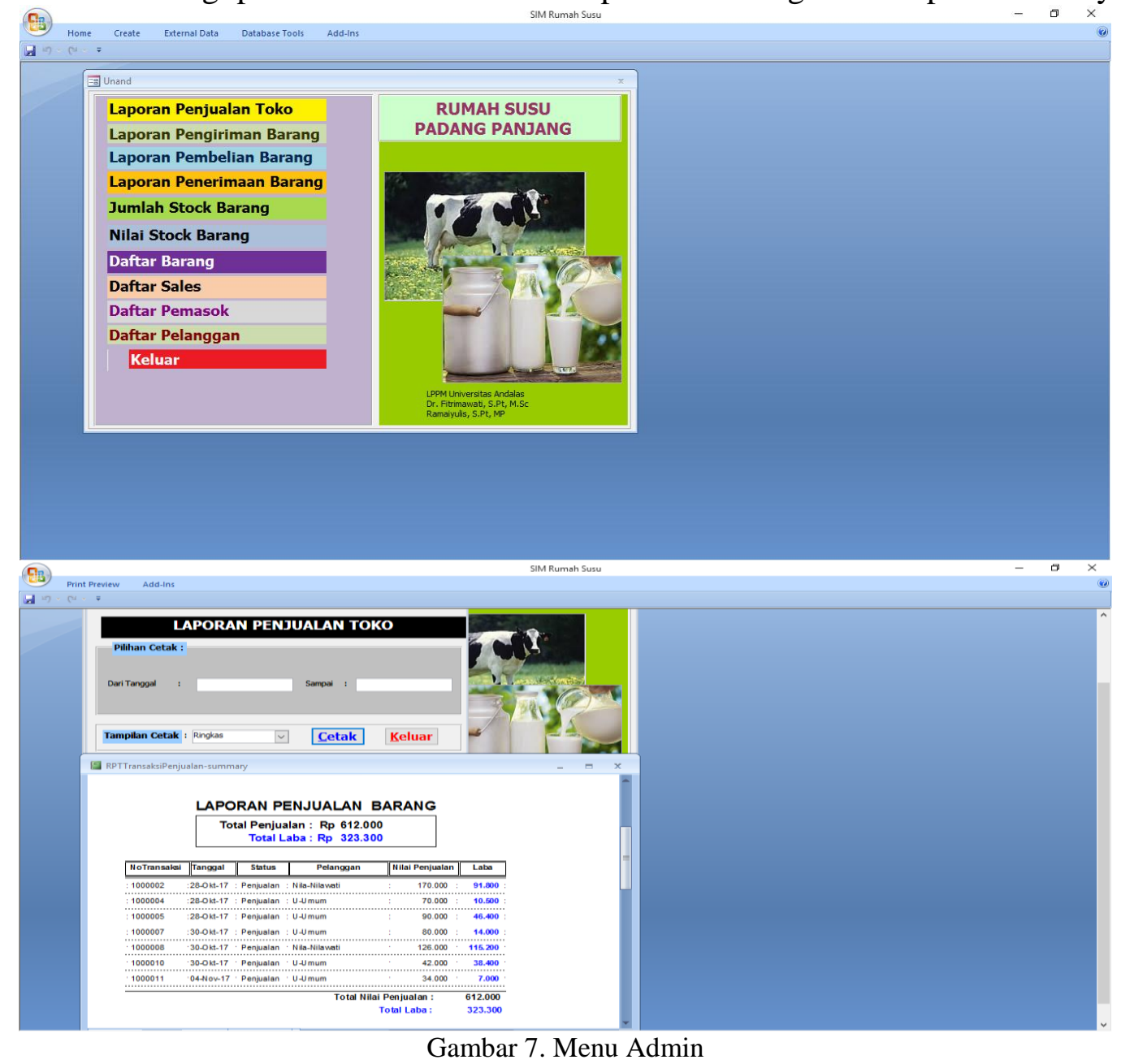


Menu di atas adalah untuk melihat hasil penjualan per satuan waktu (hari ini, bulan ini atau dari tanggal sekian ke tanggal sekian). Lalu klik \{cetak\} maka akan tampil Total penjualan harian berikut keuntungan yang diperoleh harian serta totalnya dalam kurun waktu yang dipilih. Tampilan cetak dapat diatur apakah \{Ringkas\} hanya totalnya saja dan keuntungan dari penjualan harian. Tampilan cetak \{Detil\} akan menampilkan apa saja barang yang terjual pada setiap harinya berikut total penjualan dan keuntungan harian. Ini adalah menu laporan pengiriman barang

Menu ini digunakan untuk melihat Pengiriman barang ke luar wilayah, dapat diset harian, bulanan atau dari tanggal sekian sampai tanggal sekian lalu klik \{cetak\} maka akan muncul Laporan pengiriman barang, barang apa saja yang dikirim (jika tampilan cetak "Detil") dan nilai pengiriman serta nilai keuntungan yang diperoleh. Ini adalah menu laporan pembelian barang toko.

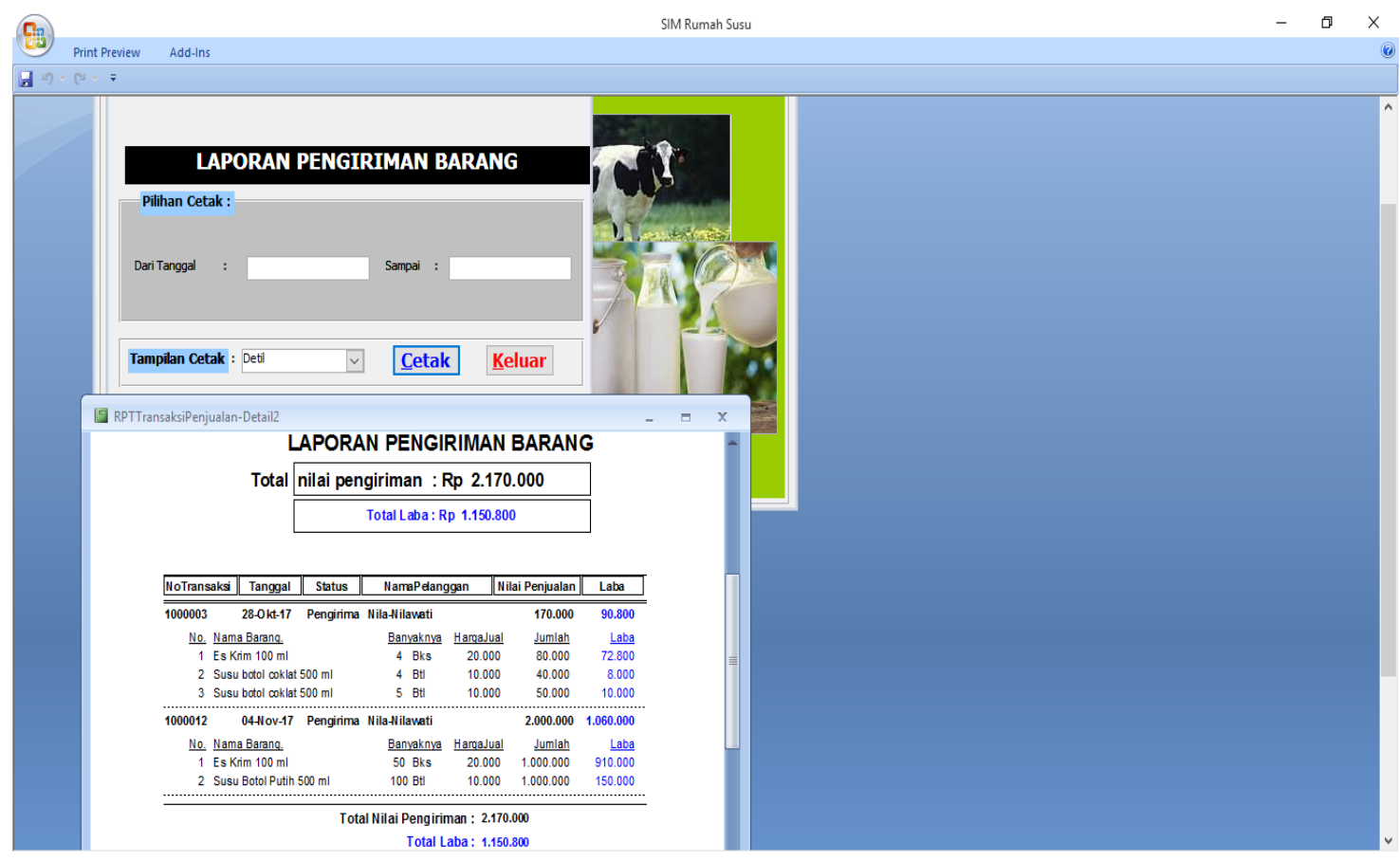

Gambar 8. Menu Laporan Pengiriman Barang 


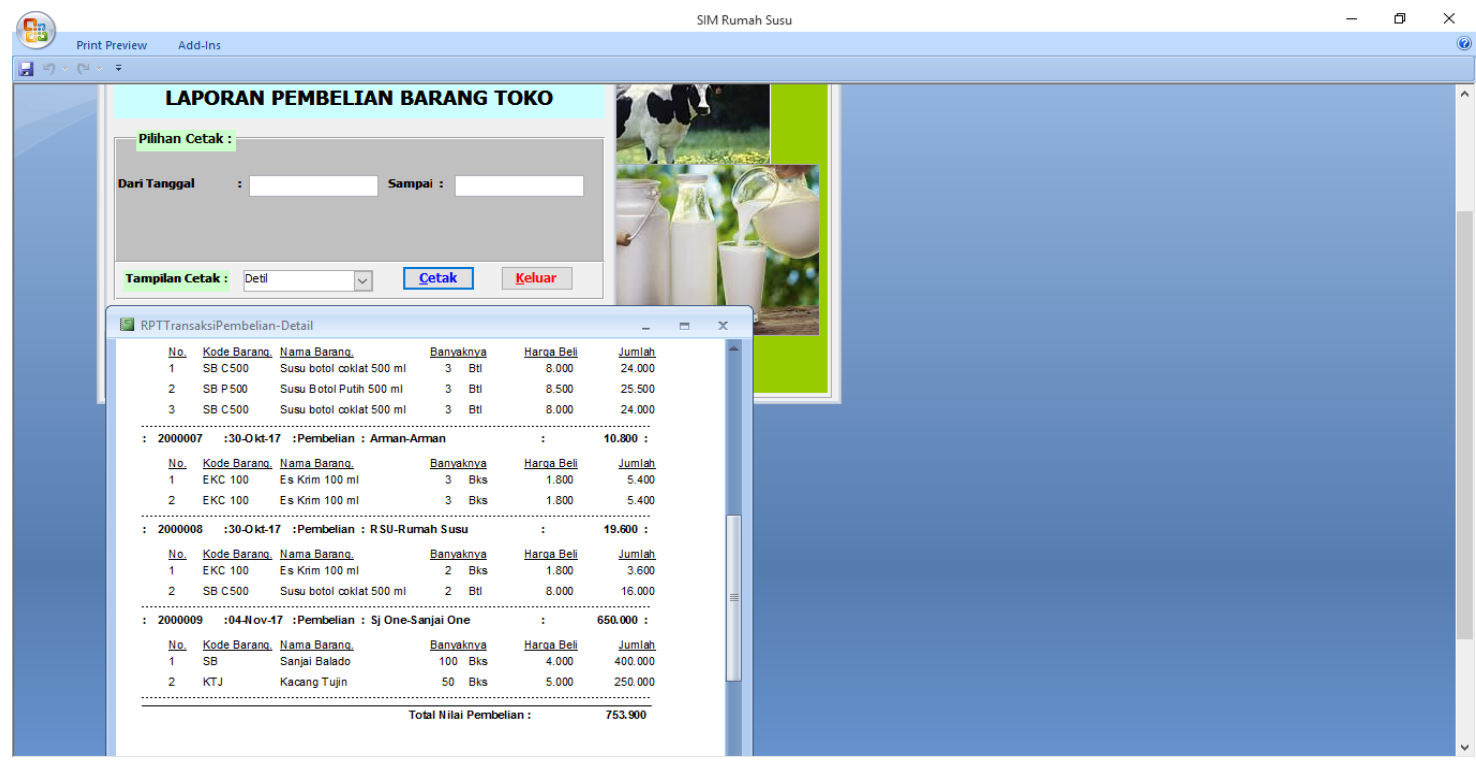

Gambar 9. Menu Pengiriman Barang

Menu ini digunakan untuk melihat pembelian barang dari luar (sanjai dll) yang telah dilakukan. Bisa dalam kurun dari tanggal sampai tanggal lalu klik \{cetak\} maka program akan menampilkan barang apa saja yang telah dibeli mualai dari tangggal pembelian, siapa pemasok , apa saja barangny dan jumlahnya serta total pembelian kepada pemasok itu dan total pengeluaran uang yang digunakan untuk pembelian pada hari itu. Ini adalah menu laporan penerimaan barang di toko dari unit pengolahan

Menu ini sangat diperlukan untuk mengontrol barang atau produk jadi yang dikirim dari unit pengolahan ke toko untuk dijual atau dikirim. Laporan bisa diset dari tanggal sampai tanggal. Jika mensetnya untuk hari ini maka tanggal diset " tanggal sekarang" sampai "tanggal besok" lalu klik \{Cetak\} maka program akan menampilkan barang apa saja yang telah diterima toko dari uni pengolahan untuk penambahan stok barang untuk dijual. Ini adalah menu laporan stok barang

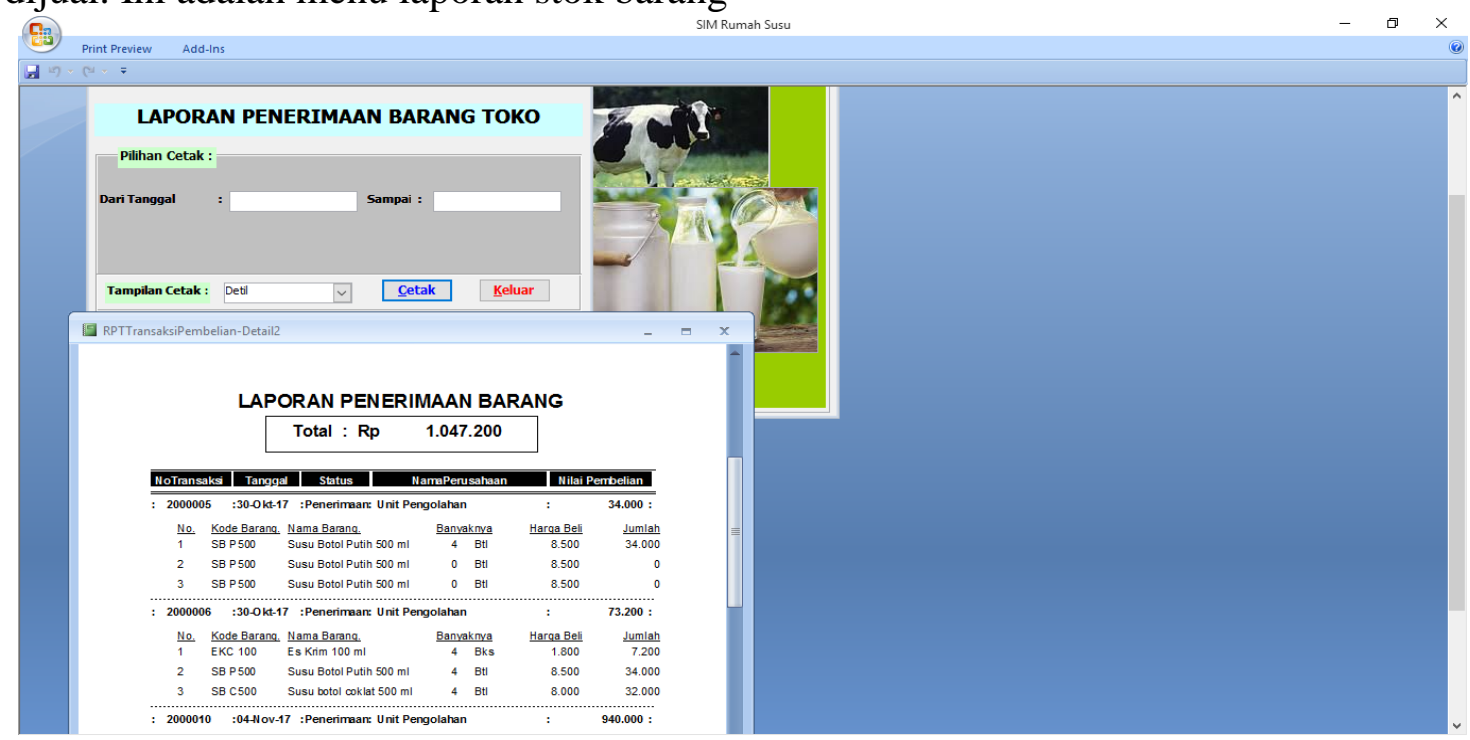

Gambar 10. Menu laporan penerimaan barang 


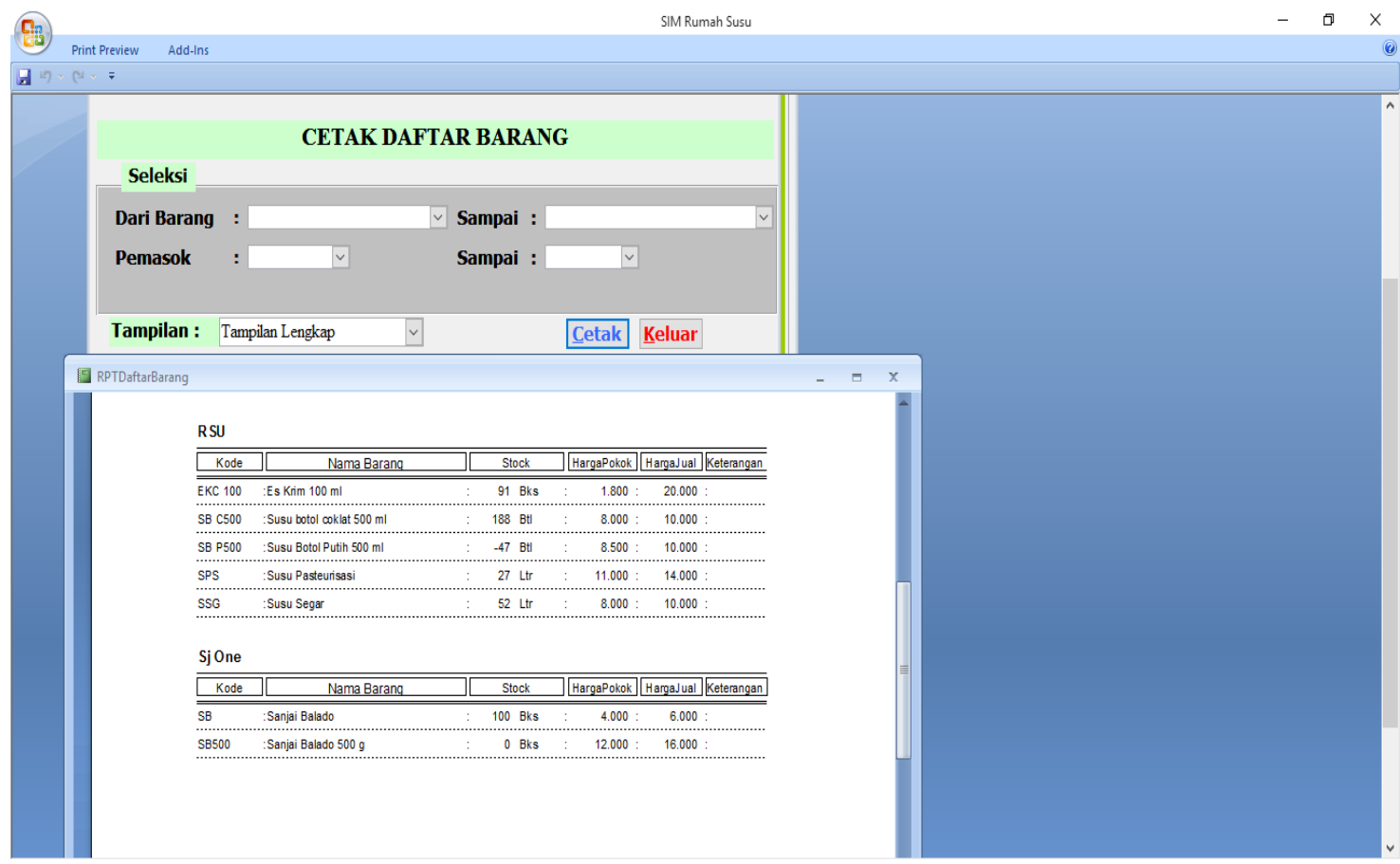

Gambar 11. Menu Laporan Stok Barang

Menu ini digunakan untuk mencek atau mengetahui :

- Jumlah Stok barang yang tersedia di toko (berdasarkan pilihan $\rightarrow$ baik barang dari luar maupun dari unit pengoalahan

- Harga jual dan harga beli barang

- Berdasarkan pilihan dapat menampilkan harga jual saja atau harga beli saja (salah satunya disembunyikan)

Ini adalah menu nilai stok barang

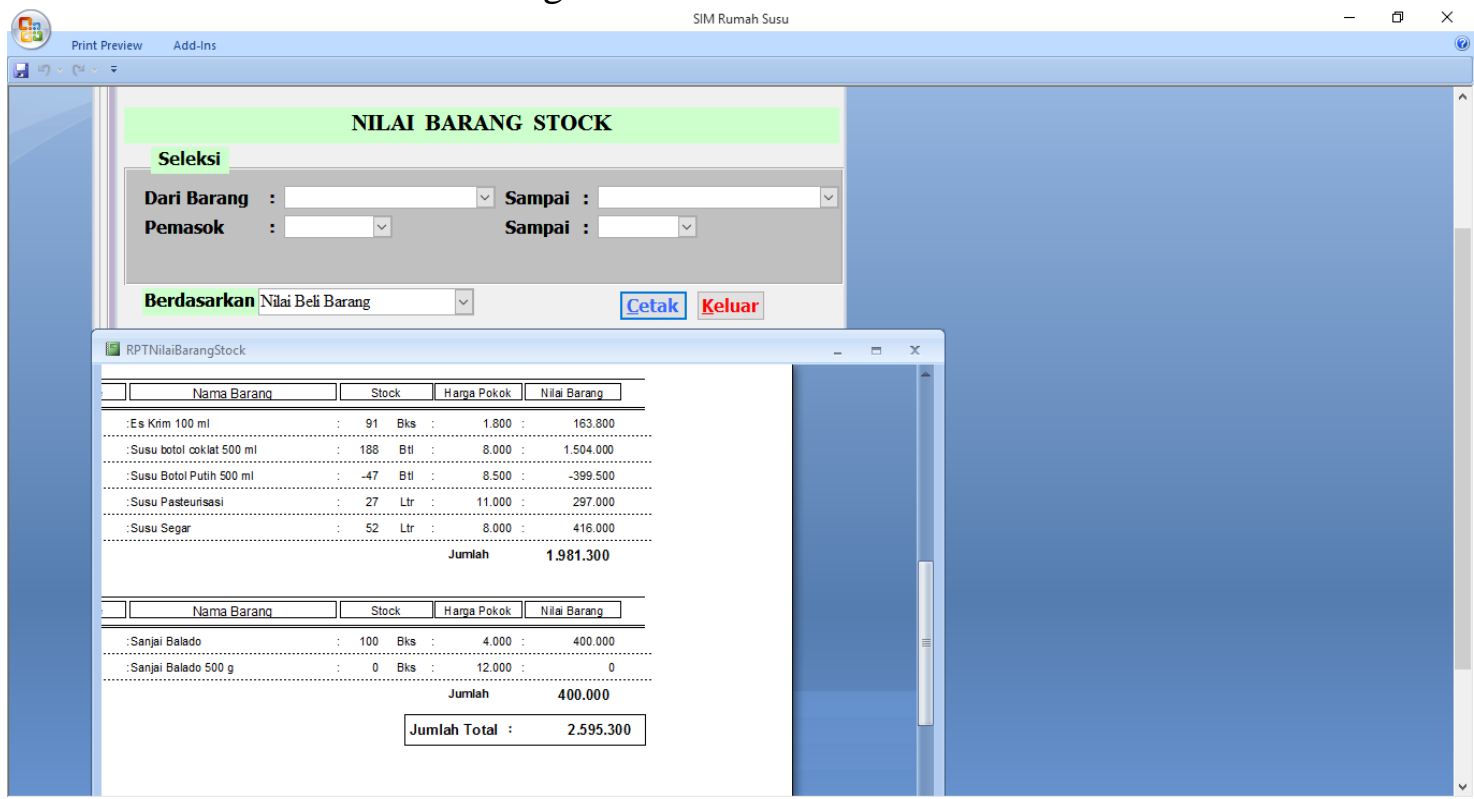

Gambar 12. Menu Nilai Stok Barang 
Menu ini diperlukan untuk mengetahui berapa nilai stok barang yang ada ditoko saat ini/ berdasarkan stok yang tersedia saat ini Berdasarkan pilihan menu dapat mengetahui nilai rupiah stok barang yang tersedia di toko yang dihitung berdasarkan harga beli barang (berdasarkan pilihan $\rightarrow$ berdasarkan harga jual barang).

Ini adalah menu daftar barang

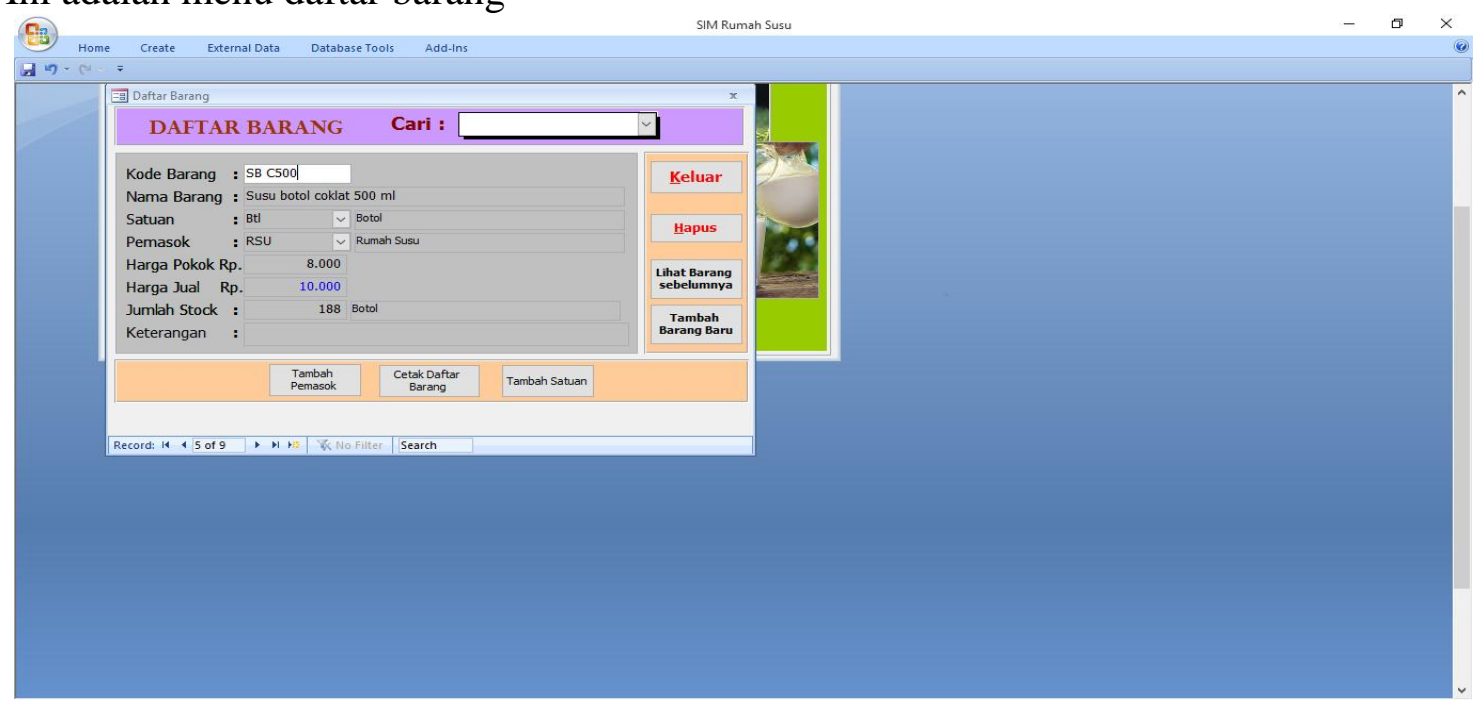

Gambar 13. Menu Daftar Barang

Sebelum program ini dioperasikan maka daftar barang ini harus diisi lengkap terlebih dahulu menginput semua jenis barang yang ada ditoko. Caranya :

- Klik tambah barang baru lalu isi kode barang

Kode barang $\rightarrow$ adalah beberapa huruf atau angka yang mudah diingat untuk keperluah kode dari barang tertentu guna keperluan agar mudah dipanggil kembali di menu penjualan, pembelian dll. Misal Susu Botol kemasan $500 \mathrm{ml}$ diberi kode : SB500. Es krim kemasan $100 \mathrm{ml}$ diberi kode : EK100. Jadi semua susu botol diberi kode SB dan bedakan ukurannya dengan angka. NB. Tidak bolah ada barang yang berkode sama (akan ditolak program dengan kata dengan tampilan berikut :

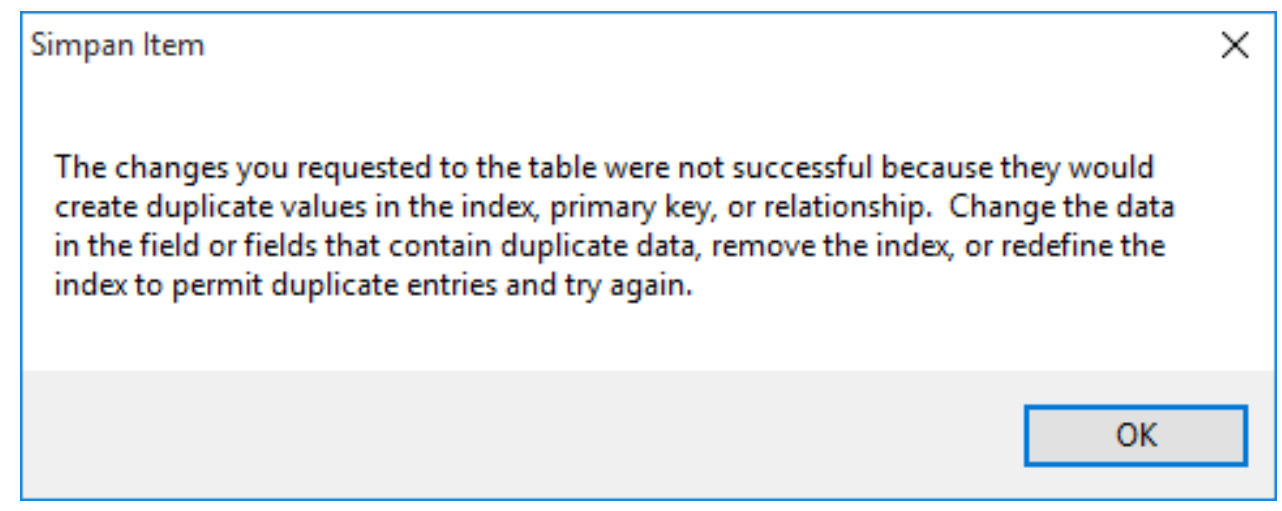

Maka berarti kode yang diinputkan sudah ada persisi sama dengan barang sebelumnya yang telah ada di program, jika terjadi klik oke dan tukar kode barang dengan yang lainnya. 
Ini adalah menu daftar sales

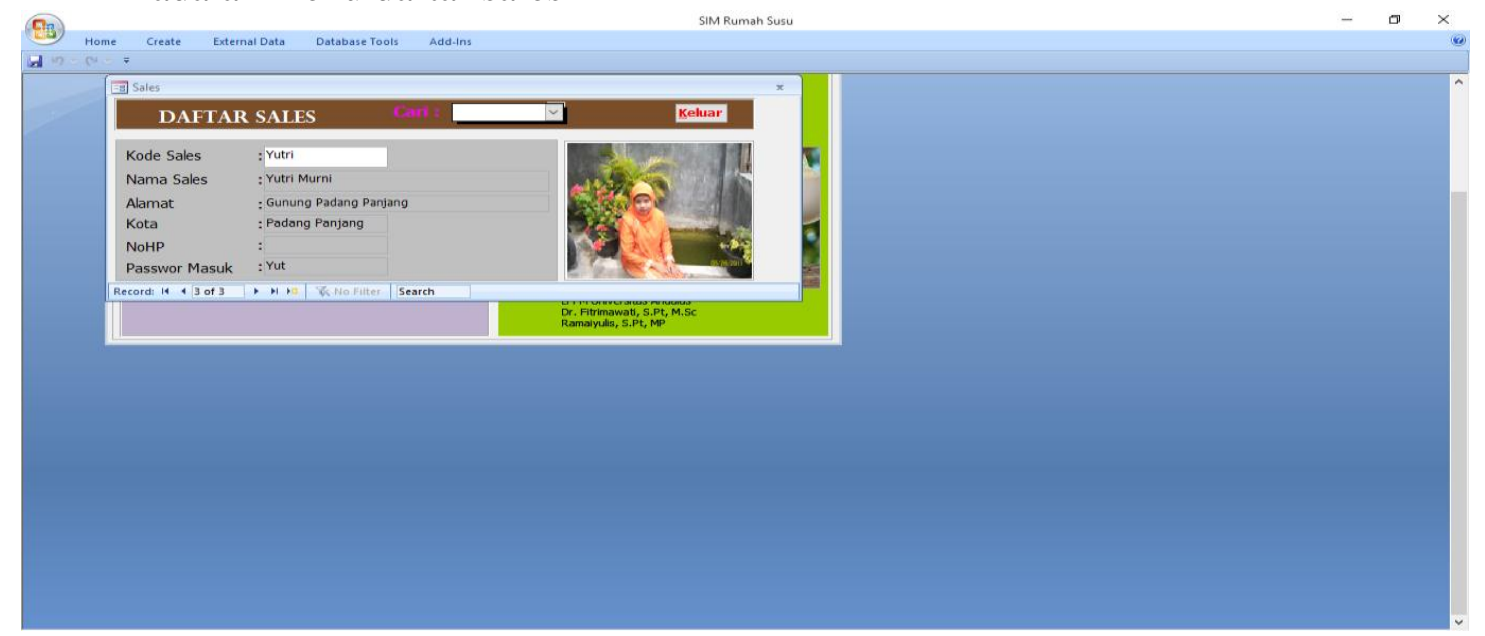

Gambar 14. Menu Daftar Sales

Diperlukan untuk input sales dan data lainnya dari sales. Disini admin dapat menentukan dan merubah password login dari sales tertentu sesuai input di password MENU PENDUKUNG :

- DAFTAR PELANGGAN

- DAFTAR PEMASOK

Kedua menu ini hanya bisa diisi pada menu admin

\section{Pelaksanaan Program Design Drive Thru}

Program pembuatan design drive thru untuk usaha Kafe Rumah Susu Padang Panjang telah dilaksanakan. Sebuah design drive thru telah diberikan kepada pihak mitra. Pihak mitra antusias sekali dengan anjuran team pengabdi untuk membuat drive thru sederhana. Anjuran untuk membuat drive thru sederhana ini bertujuan untuk meningkatkatkan penjualan dan agar peluang pasar yang amat besar yang berasal dari wisatawan dapat ditanggap secara maksimal.

Kegiatan pertama yang dilakukan team pengabdi adalah berdiskusi dengan mitra tentang manfaat drive thru dan pihak mitra memberikan informasi tentang lokasi beserta ukuran lokasi pembuatan design drive thru sederhana di kafe rumah susu. Kemudian team merancang design drive thru dan kembali berkunjung ke tempat mitra untuk memberikan sebuah design drive thru sederhana seperti gambar di bawah ini: 


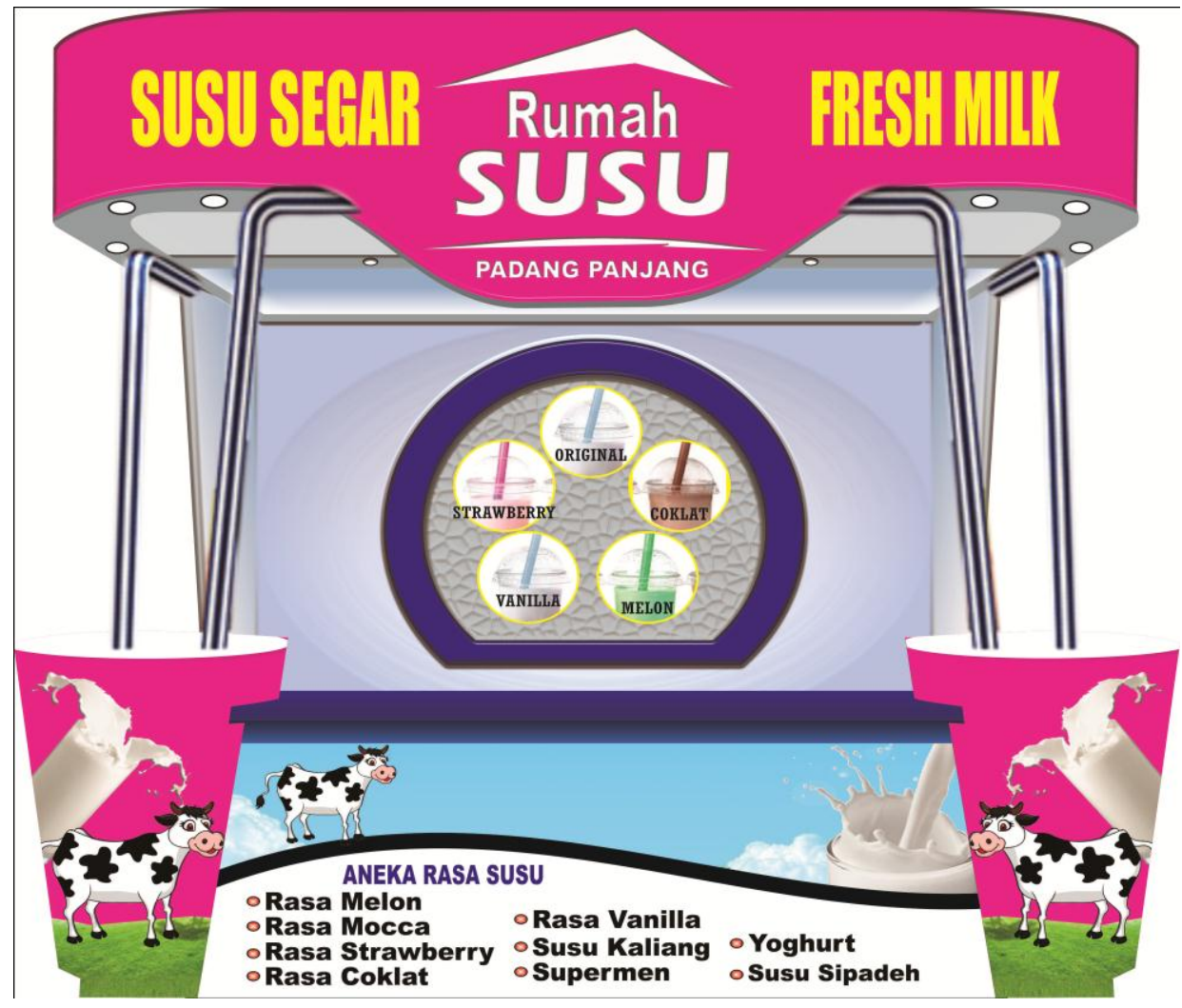

Gambar 15. Design Drive THRU

\section{KESIMPULAN DAN SARAN}

\section{Kesimpulan}

Aplikasi SIM ini dapat bermanfaat bagi mitra Usaha Kafe Rumah Susu Padang Panjang mendapatkan informasi yang sangat dibutuhkan untuk menentukan keputusan manajemen yang tepat dan efektif. Semua informasi usaha dapat tersedia dengan cepat dan mudah dengan dukungan Sistem Informasi Manajemen ini. Penerapan SIM dalam usaha mitra berperan penting sebagai pengaman harta kekayaan perusahaan dan sebagai penunjang proses pengambilan keputusan. Dengan adanya unsur-unsur pengendalian atau pengecekan dalam sistem berbagai kecenderungan, penyimpangan dan kesalahan dapat dihindarkan atau dilacak sehingga dapat diperbaiki. Hal ini amat dibutuhkan sekali oleh mitra karena pemilik usaha yaitu Ibuk Erni Wati karena usaha ini dioperasionalkan dan didelegasikan kepada seorang manager dimana pemilik tidak setiap hari ataupun setiap waktu berada di lokasi usaha. Pengolahan transaksi usaha yang selama ini menjadi permasalahan utama perusahaan karena keterbatasan kemampuan pengusaha dan karyawannya, dapat terpecahkan dengan menggunakan SIM. Pembukuan dengan SIM dapat dilakukan sendiri oleh perusahaan. SIM mampu mengolah data dan menyediakan informasi mengenai kondisi usaha yang sangat dibutuhkan oleh manajer.

Demikian juga design drive thru yang diberikan kepada pihak mitra usaha kafe rumah susu Padang Panjang akan direalisasikan sesegera mungkin dan jika diizinkan Allah akhir tahun ini sudah terealisasi. Pihak mitra menyadari akan manfaat penjualan 
dengan sistem drive thru. Program ini mendorong semangat mereka untuk mengembangkan usahanya melalui sistem penjualan drive thru serta menambah keyakinan mereka terhadap perkembangan penjualan mereka. Pihak mitra merasakan ada solusi baru terhadap terhadap peningkatan penjualan produk mereka

\section{Saran}

Diakhir pertemuan, pihak mitra usaha kafe rumah susu Padang Panjang mengucapkan terima kasih atas pembuatan sistem informasi manajemen untuk usaha mereka dan mengajarkan cara mengaplikasikannya serta pemberian satu design drive thru beserta informasi harganya. Pihak mitra akan mengaplikasikan sesegera mungkin SIM dan layanan drive thru ini di usahanya.

\section{UCAPAN TERIMA KASIH}

Kami tim pengabdi mengucapkan terima kasih kepada Lembaga Penelitian dan Pengabdian kepada Masyarakat (LPPM) Universitas Andalas yang telah mempercayakan kami untuk melaksanakan kegiatan ini. Berkat materil dan moril diberikan maka artikel ini dapat dipublikasikan.

\section{DAFTAR PUSTAKA}

Alter, S. 2009. Information Systems : A Management Perspective. The Benjamin/ Cummings Company, Inc.

BPS. 2010. Sumatera Barat dalam Angka. Badan Pusat Statistik Sumatera Barat. BPS, Padang.

O’Brien, J.A. 1996. Management Information Systems: Managing Information Technology in the Networked Enterprise. 3th Ed. Times Mirror Higher Education Group.

Kadir, A. 2003. Pengenalan Sistem Informasi. Penerbit Andi, Yogyakarta.

Ramaiyulis, 2006. Teknik Desain Database. Buku Penuntun Praktikum Aplikasi Komputer Bisnis. Politeknik Pertanian Negeri Payakumbuh, Payakumbuh.

Widjajanto, N. 2001. Sistem Informasi Akuntansi. Penerbit Erlangga, Jakarta. 